\title{
Impact of Massification on Resource Adequacy in Public and Private Universities in Kenya
}

\author{
Wilberforce N. Mwirichia ${ }^{1, *}$, Nelson Jagero ${ }^{1} \&$ Hillary Barchok $^{1}$ \\ ${ }^{1}$ Chuka University, Chuka, Kenya \\ *Correspondence: Chuka University, Chuka, Kenya. Tel: 254-728-061-501. E-mail: \\ Wmwirichia@Yahoo.Com
}

Received: July 10, 2017 Accepted: August 2, 2017 Published: September 15, 2017

doi:10.5296/ije.v9i3.11874 URL: https://doi.org/10.5296/ije.v9i3.11874

\begin{abstract}
The purpose of the study was to determine the impact of resource adequacy in public and private universities in Kenya. Massification is the rapid enrolment of students in universities. Kenya has expanded her student enrolment in universities for her development needs. Research findings raise pertinent issues touching on the quality of education in the Kenyan universities. The study adopted a causal- comparative survey research design. The respondents were students and lecturers in the eight purposely selected universities in Kenya. A sample of 399 respondents consisting of 361 students, 22 lecturers and 16 heads of Department from four public and four private universities in Kenya were selected for the study through simple random sampling technique. The inferential statistics used in the study was chi-square. The hypothesis of the study was stated as "there is no statistical significant difference on the impact of massification on resource adequacy between public and private universities in Kenya. The study found that there is no significant statistical difference on the impact of massification on resource adequacy between public and private universities. From the study it was concluded that there was no statistical significance difference on the impact of massification on resource adequacy between public and private universities in Kenya. The study recommends that university management in public universities should provide adequate learning, welfare services, computing services and human resources to improve the quality of education and training in the universities in Kenya.
\end{abstract}

Keywords: massification, Resource Adequacy, Chi-square, private universities, public universities. 


\section{Introduction.}

Statistics show that there has been mass enrolment of students in universities all over the world outstripping the available resources, a phenomenon described as massification (Mohammedbhai, 2008). Massification can be viewed as a global phenomenon resulting from such factors such as democratization of education, the advent of knowledge economy and globalization. (Mohammedbhai, 2008).

In 2005, according to Trows (2000) countries in North America and Western Europe had undergone massification. Rapid enrolments of students have also been found in China, Korea, Japan and Mongolia (Postiglione \& Tan, 2007). UNESCO Institute for Statistics (2010) indicates that African countries have experienced massification in their universities.

Rapid enrolment of students in Kenyan universities has strained resources such as financial and physical infrastructure leading to inadequate student instructional materials. A study on the effects of massification by Abagi, Nzomo and Otieno (2012) in Kenyatta University and University of Nairobi found that massification in universities may have compromised their effectiveness in imparting knowledge and skills to the students. In private universities, the quality of education has declined (Gudo, Olel, \& Oanda, 2011; Mbirithi, 2003). Studies have been carried out on the effect of massification on universities in Kenya. However, there has been no comparative study on the impact of massification on resource adequacy in private and public universities in Kenya. It is imperative, therefore, to understand the impact of massification of students on resource adequacy in both private and public universities in Kenya. Thus, the present study sought to compare the impact of massification on resource adequacy in public and private universities in Kenya. The hypothesis of the study is stated thus, 'there is no statistical significant difference on the impact of massification on resource adequacy between public and private universities in Kenya. The study hypothesis was tested at $\alpha=0.05$.

\section{Literature Review}

Massification has affected university's' resource adequacy all over the world. The effect has been on public universities as well as in private universities. In Europe, private universities have shown weak infrastructure, relatively full-time academic faculty (Guri-Roseblit \& Sebkora, 2014).

In Asia, the resource adequacy in the universities has been a problem. In China, for example, the student per teacher is close to 1 to 5 in 2003 (Boye, 2014).In Africa, there has been a shortage supply of human resources such that the ratios of lecturers to students were 1: 30 in most universities while some departments were experiencing ratios of up to 1:100. According to Okebukola (2014) for instance, Nigerian universities ratio of staff to students is 1:100. Ahemba (2006) describes many African universities as being in a state of crisis since they lack basic infrastructure such as internet connectivity, books, laboratory equipment and classroom. 


\section{Ml Macrothink}

International Journal of Education

ISSN 1948-5476

2017, Vol. 9, No. 3

In Kenya, there are numerous threats ranging from inadequate qualified personnel to shortage of accommodation for students. A study in Kenyan universities by Mutisya (2010) indicated that there was shortage of lecturers in the universities. Previous studies by Chege (2006) and Eshiwani (2009) found that there were inadequate lecture halls; students' accommodation and so on. It is important to note that in the 1990/91 academic year, the double intake at Kenya universities caused lack of adequate size and that the existing facilities were characterized by serious congestion. The study compares the opinion of lecturers and students in universities on resource adequacy as they are implementers and recipients of university curriculum respectively.

\section{Methodology}

\subsection{Research Design}

The study adopted a causal -comparative research design. It points out the similarities and explains differences among variables under study. The researcher has no chance of manipulating the independent variable.

\subsection{Population and Sample Size}

Table 1. Universities and Sample Size

\begin{tabular}{lccc}
\hline \multirow{2}{*}{ Category } & \multicolumn{3}{c}{ Sample Size } \\
\cline { 2 - 4 } University & Students & Lecturers & Total \\
\hline University of Nairobi & 122 & 3 & 125 \\
Kenyatta University & 133 & 2 & 135 \\
Moi University & 74 & 2 & 7 \\
Egerton University & 44 & 1 & 45 \\
Strathmore University & 9 & 1 & 10 \\
Catholic University of Eastern Africa & 9 & 1 & 10 \\
University of Eastern Africa, Baraton & 9 & 1 & 10 \\
Daystar University & 9 & 1 & 10 \\
Total & 409 & 12 & 421 \\
\hline
\end{tabular}

Source: Authors generated information from University databases, Daily Nation (Kenya) and Commission of University Education (Kenya).

The accessible population for this study was 179,427 respondents consisted of 175, 249 students and 4,178 lecturers from eight universities selected for the study. According to Krejecie and Morgan (1970), an accessible population of 179, 427 have a normal sample size of 384. Thus, 384 were shared out among the universities using proportionate sampling. The universities consisted of University of Nairobi, Kenyatta University, Moi University, Egerton University, while private universities were Strathmore University, Catholic University of Eastern Africa and University of East Africa, Baraton. The distribution of respondents' sample by universities is shown in Table 1 . 


\subsection{Sampling Procedure}

Proportional sampling was used to compute respondents from each university. A total of 421 respondents were involved in the study.

\subsection{Data Analysis}

The data was analyzed using inferential statistics. Inferential statistics used was a chi-square. The hypothesis was tested at a level of $\alpha=0.05$. The quantitative data was analyzed by use of Statistical Package for Social Sciences (SPSS) computer software version 21.

\section{Results and Discussion}

The research findings are analyzed using inferential statistics. The study aimed at determining the impact of resource adequacy between public and private universities in Kenya. Resources used in universities were library facilities, number of lecturers, lecture rooms and so on. The information on resource adequacy was sought from students and lecturers in both private and public universities in Kenya.

Table 2. Chi-square test of Students' Responses on Adequacy of Resources in Public and Private Universities

\begin{tabular}{lllll}
\hline Resource & Chi-square & df & p-value & Interpretation \\
\hline Library space & 19.135 & 4. & 0.177 & No difference \\
Library facilities & 10.206 & 4 & 0.061 & No difference \\
Science lab facilities & 10.398 & 4 & 0.134 & No difference \\
Science lab space & 8.759 & 4 & 0.067 & No difference \\
Engineering workshops & 16.159 & 4 & 0.083 & No difference \\
Agriculture workshops & 13.227 & 4 & 0.310 & No difference \\
Laboratory equipment & 3.078 & 4 & 0.545 & No difference \\
Housing facilities for students & 24.543 & 4 & 0.070 & No difference \\
Lecture rooms & 29.835 & 4 & 0.200 & No difference \\
Number of Lecturers & 5.357 & 4 & 0.253 & No difference \\
Students Counseling Services & 23.355 & 4 & 0.056 & No difference \\
Core- texts & 6.001 & 4 & 0.199 & No difference \\
Academic journals & 8.759 & 4 & 0.067 & No difference \\
Internet services & 25.269 & 4 & 0.057 & No difference \\
Number of computers & 30.511 & 4 & 0.067 & No difference \\
Catering facilities & 18.189 & 4 & 0.051 & No difference \\
No of administrative Staff & 16.465 & 4 & 0.052 & No difference \\
Overall & $\mathbf{1 5 . 8 3 9}$ & $\mathbf{4}$ & $\mathbf{0 . 1 4 4}$ & No difference \\
\hline
\end{tabular}

To find out whether there was any difference on the impact of massification on resource adequacy between public and private universities based on student's responses a chi-square test was performed. The results of analyses are presented in Table 2. 


\section{Macrothink}

International Journal of Education

ISSN 1948-5476

2017, Vol. 9, No. 3

An inspection of the results of chi-square test in Table 2 shows that there is no significant difference on the impact of massification on resource adequacy between public and private universities in Kenya based on students' responses. The null hypothesis which stated that there is no statistical significant difference on the impact of massification based on students' responses was therefore accepted. That is $(\chi 2==15.839, \mathrm{p}>0.05)$

Also a Chi-square test was computed on the impact of massification on resource adequacy between public and private universities based on lecturers' responses

The results are presented in Table 3.

Table 3. Chi-square test of Lecturers' Responses on Adequacy of Resources in Public and Private Universities

\begin{tabular}{lllll}
\hline Resource & & & & \\
\hline Library space & Chi-square & df & p-value & Interpretation \\
Library facilities & 8.484 & 3 & 0.037 & Difference \\
Science lab facilities & 6.777 & 2 & 0.034 & Difference \\
Science lab space & 1.698 & 3 & 0.637 & No difference \\
Engineering workshops & 0.551 & 3 & 0.908 & No difference \\
Agriculture workshops & 12.838 & 2 & 0.057 & No difference \\
Laboratory equipment & 0.577 & 2 & 0.749 & No difference \\
Housing facilities for students & 7.368 & 4 & 0.118 & No difference \\
Lecture rooms & 4.035 & 3 & 0.268 & No difference \\
Number of Lecturers & 15.783 & 4 & 0.003 & Difference \\
No of administrative Staff & 3.434 & 4 & 0.023 & Difference \\
Core- texts & 4.502 & 4 & 0.342 & No difference \\
Academic journals & 6.224 & 3 & 0.101 & No difference \\
Internet services & 7.241 & 3 & 0.065 & No difference \\
Number of computers & 3.742 & 3 & 0.291 & No difference \\
Catering facilities & 9.681 & 4 & 0.046 & Difference \\
Office for lecturers & 5.689 & 3 & 0.128 & No difference \\
Overall & 4.486 & 4 & 0.344 & No difference \\
\hline
\end{tabular}

The information in Table 3 reveals that there is no significant difference on the impact of massification on resource adequacy between public and private universities based on lecturers' responses. That is $(\chi 2==6.065, \mathrm{p}>0.05)$.

The information in Table 2 and Table 3 reveals that there is no statistically significant difference on the impact of massification on resource adequacy between public and private universities based on students' and lecturers' responses. The hypothesis (H01) that stated that there is no statistical significant difference on the impact of massification on resource adequacy between public and private universities in Kenya was accepted. The results showed 
that there is no statistical significant difference on the impact of massification on resource adequacy between public and private universities in Kenya confirms findings of Mbirithi (2003) and Eshiwani (2009) in Kenya. Their studies found that universities in Kenya suffer from inadequate educational resources such as faculty staff, internet services and so on. Studies in Africa by Okwakol (2008) and Afolabi (2005) in universities in Nigeria found that universities are experiencing shortages of academic staff and other resources. Studies in Bangladesh by Boye (2014) showed that it's universities suffers from shortage of resources such as books and online communication.

\section{Conclusion}

The aim of the study was to find out the impact of massification on resource adequacy between public and private universities in Kenya. This study found that there were inadequate resources in public and private universities in Kenya.

The hypothesis of the study was that there is no statistically significant difference on the impact of massification on resource adequacy between public and private universities in Kenya. The finding was that there is no statistically significant difference on the impact of massification on resource adequacy between public and private universities in Kenya. The hypothesis that there is no statistically significant difference on the impact of massification of universities on resource adequacy between public and private universities in Kenya was accepted.

\section{Recommendations}

University authorities need to increase the funding of universities specifically, public universities so as to increase their efficiencies in provision of quality education.

\section{References}

Abagi, O., Nzomo, J., \& Otieno, W. (2012). Private Higher Education in Kenya. https://www.researchgate.net

Afolabi, S.O. (2005). Statistical Tools and Models for Educational Planners. Ilorin: Integrity Publications.

Boye, E. (2014). Bangladesh: Public- Private Partnership in Higher Education. M.A. Mannan.

Chege, M. (2006). The State of Higher Education in Kenya: Problems and Prospects. Paper Presented at the 'Mijadala Social Policy, Governance and Development in Kenya, Sponsored by Development Policy Management Forum.

Eshiwani, G. (2009). University Expansion in Eastern Africa: Challenges and Options in 
Higher Education. Inter-University Council for East Africa (IUCEA). Newsletter, 3, 17-22.

Gudo, C.O., Olel, M.A., \& Oanda, I.O. (2011). Students Admission Policies for Quality Assurance: Towards Quality Education in Kenyan Universities. International Journal of Business and Social Sciences, 1(8), 177-183.

Guri- Rosenblit, S., \& Sebkova, H. (2004). Diversifiation of Higher Education Systems: Patterns,Trends and Impacts. UNESCO. Forum Series. Paper No.6." Diversification of Higher Education and the Changing Role of Knowledge and Research", 40-69.

Krejecie, R., \& Morgan, D. (1970). Determining Sample Size for Research Studies. Education Business and Social Sciences, 1(8), 177-183.

Mbirithi, D.M. (2003). Management Challenges Facing Kenya's Public Universities and Implications for the Quality of Education. Ph.D. Thesis. Kenyatta University, Kenya.

Mohammedbhai, G. (2008). The effect of Massification on Higher Education in Africa. https://erepository. Uonbi. ac.ke

Mutisya, K. (2010). How the Wrong Policies turned Public Universities into Cacophonous Markets. Daily Nation. Nairobi: National Media Group.pp.13.

Okebukola, P A. (2014). Challenges and Prospects for Quality Assurance in Science and Technology Education in African Countries. The Uganda Higher Education Review. Journal of the National Council for Higher Education, 5(2), 17-26.

Postiglione, G., \& Tan, J. (2007). Going to School in East Asia.NewYork: Greenwood Press.

Trows, M. (2000). From Mass Higher Education to Universal Access.The American Advantages Research and Occassional Paper Services. Berkley: Center for Studies for Higher Education.

\section{Copyright Disclaimer}

Copyright for this article is retained by the author(s), with first publication rights granted to the journal.

This is an open-access article distributed under the terms and conditions of the Creative Commons Attribution license (http://creativecommons.org/licenses/by/3.0/). 